\title{
The Strategic Leadership and the effect in the Development of an Iraq Oil Industry
}

\author{
Jawad Al-Frijawy*, Constantin Militaru, Sergiu Tonoiu
}

\author{
Faculty of Engineering and Management of Technological System, University Polytechnic of Bucharest, RO-060042, Bucharest, \\ Romania \\ *Corresponding Author
}

\begin{abstract}
This research paper is to the identify an extent and practice of the Strategic leadership and its relationship with the Iraq oil industry, The researcher used a descriptive analytical approach, Designed specifically for data collection, 130 questionnaire was distributed to employees Iraq oil companies and retrieved 114 valid questionnaires for statistical analysis, The outcome showing that there are the positive relations between (supporting senior management the strategic leadership and a trends illustrating a strategy in the oil sector). A number of conclusions were reached, the most important being a relationship between practice and the role of the strategic leadership on the oil Iraq industry.
\end{abstract}

Keywords- Iraq oil industry, Strategic leadership, Development.

\section{INTRODUCTION}

Higher echelons theory suggested a specified knowledge, experiment, value and cucumber from top managers affect those respect an environment and strategy decisions those made. In the past 30 years, this theory was expanding to what they know now represented the strategic leadership theories.(Hambrick. D. C., and Mason, P. A., 1984).As strategic leaders which in general include a leader executive officer and them higher management staff, and a board of HR. the opinion of the strategic leaders is differentiated of oversight theory of the strategic leadership on a former is worried about the leadership of companies, however a focus in leadership in companies (Finkelstein, S., Hambrick, D. C., and Cannella, A. A ., 2009).The critical frailty on our flow knowledge from the strategic leadership is the shortage of the integration between micro, and the macro-perspective of the leadership, and a lack of discussion, through leadership scientists on organizational behavior, and the strategic administration domain. That lack of integration and the discussion leaders to multiple terminologies and disconnect constructs, intervention research questions, research not building in the right result, broken, of the different theories. Of the try towards integration exemplify on a critical review(Boal, K. B., and Hooijberg, R., 2001).It was Publishing in the leadership quarterly: the suggested the complementary sample connection modern leadership theory (ex. view, the gravitational and transfer leaders) and emerging leadership theory (ex. leaders person differences, through personality, and cognitive factor, as long as behavioral complication) with the strategic leaders' effect.(Crossan, M., Vera, D., and Nanjad, L., 2008).Presented the integrative scope of responsibility of the strategic leaders through the leadership of a self (ex.person-consciousness and the developed of characters power) the leadership of the others (ex. technicality of interpersonal impact), and the leadership of the organizations (ex. alignment of the environment, strategy, and organization). That initial complementarity effort was compatible with the flow discussion in a micro-companies view from the strategic (Felin, T., and Foss, N ., 2005).Actually, understanding the strategic leadership include highlighting what efficient top leaders, in fact, do in this system to produce the strategy leadership-focus organizations (Rumsey, M. G., 2013).Moreover, the strategic leaders request to could a focus on a serious resource whose is more like to made the difference on a confirmation from the sustained the future of the success(Hitt, I., Ireland, R., and Hoskisson, R. E., 1995).However, who was recommending that the strategic leadership is almost winning arrival in the key resource this as coalitions with accomplice companies' social capital" and capabilities to building big team human capital, as the most essential companies' resource. A strategy review of literature emphasizes the active the strategic leaders' capacity are indeed on new competitors a landscape expecting, for the 21st century(Ireland, R. D., and Hitt, M. A., 2005).Maybe the most mission for the strategic leaders this active on management the companies' of the resource. 
Strategic leader succeeds the company's portfolio from the resource by regulating their till capacity, building companies to using the ability, and development and investigation the strategic leadership to influence these resource(Sirmon, D., Hitt, M., and Ireland, R. D., 2007).Strategic leadership is the integral ingredients from a strategic administration operation, and this a consideration as an operation the transforms a formulated strategic to the chain of action, and the outcome into including the vision, mission, strategy the goals from companies is success achieved planning(Thompson, A.A. and Strickland, A.J., 2003).Strategy leader has the roles into play in all of a mentioned strategy leadership action. Conversely, all of that strategic leadership reactions actively contributes to an efficient strategic achievement(Hitt, M.A., Ireland, R.D. and Hoskisson, R.E ., 2007).Strategy leaders are the chain from decision and effectiveness, both process oriented, and fixed on nature, during whom, over time past, present and the future from the companies integrate. The Strategy leadership model the bridge between past a present, and a future, by reaffirmed essence importance, to include continuity, and safety as a companies' contention with wellknown, and unknown fact and probable. The Strategy leadership development focus and become an organization constitutional human and public capital, and capacity to meeting true-times opportunities and threat. Lastly, the strategy leadership made feels of award means into environment disorder and ambiguous, and provide the vision, and on the way map allows the companies to develop and innovate(Boal,K. B., 2004, August 17-20).

\section{Iraq Petroleum Industry}

Iraq has a world's third- large oil reserve. Moreover, a developing of Iraq petroleum sector was cruelty disabilities by the contract of the war, sanctions, weak investment, an exodus outcome of the technocrat and the vandalism. Correctional Iraq's oil infrastructures and expansion developing and the product is of fundamental importance to a country in the future. Accordance with the dated the publicly an available scanning, there are 28 large fields on Iraq, who contract a predestined $12 \%$ of complete certain global reserves. The finder as the early adage an Ottoman, large gigantic fields on Qurna (same called West Qurna or Qurna $1 \& 2$ ) is as well located on a Basra Governorate. Majnoon field in a north Basrah this the 3 large gigantic fields in Iraqi. All of that field are predestined into being between a 3rd and a 9th large fields on the world.An exceptional scale from the field and then much-sustained production is due to the almost ideal combinations from an importance subterranean geologic framework and the highly enforceable reservoir. Those private sedimentary properties made the extremely recovery (capacity to exception the height proportion from the giant fields) and prosper contribute (and knows a number from success well completed as split into by a number of good excavation) between a high on the world. Therefore, a closeness from those gigantic fields to applicable ports for unloading by pipelining in the Umm Qasr. The closeness to the port, height success and the recovery rate, the along-with amazing geologic properties from petroleum some, contribute into the height profitable award to any IOC interested to attractions on a sizable risk linked with the Iraqi investment(Thomas W., 2010).

\section{RESEARCH OBJECTIVES}

Essential objectives from the research are to discussing the perceived roles from the strategic leadership on the strategy achievable in oil Iraq companies. That well of done on the efforts to allowed rules and guidance for the efficient was the use of the strategic leadership on general, and specified the strategy leadership reactions in special, as the drivers from the strategic achievable on oil Iraq companies.

Realize an essential objective, the objective of the study is to discuss:

- A understand the efficiency of the strategic achievable in oil Iraq companies.

- A understand barriers into the strategic achievable on oil Iraq companies.

- A understand drivers of change of the strategic leadership achievable in oil Iraq companies .

- A understand roles of the strategic leaders achievable in oil Iraq companies in general, and specifically in the terms of an achievable strategy.

\section{Determining the Strategic leadership Direction}

The upper management teams should develop an explicit vision for companies. Expressing and the communications from the fomenting vision crucial task of strategic leadership from the companies. Those need to paint the pictures, where the companies It will be in 4-12 years and bring employees into until and do into the futures. A vision shall request into the push and beyond staff stretch those stream expectancy. A vision interests as the destination into companies and Thus as information into strategic leadership formula and achievement. Additionally, a vision launched by the upper management teams must outline essential value and an ideological the companies intend into "life by. If it is too has any effect, a vision should communicate and cultivated throughout companies and over-times. Besides, 
discussing the need to interpret the generality of a vision until measurable — or specific goal — with adhered from each the management levels and regions of business.

\section{Nature of strategy leadership style}

Furthermore to the effectiveness or the responsibility of upper administration teams, as summarized on an antecedent section, into understanding interaction of leadership, and strategic, it's advantageous into look in a style from strategic leadership senior management may be used. Therefore, emphases a needs in the top from the companies of what label "Strategy Leadership". Describe Strategy Leadership as a capacity to impact others into a voluntarily made day into day resolution the improves longrange survive from companies however maintain it is the long-range financial stabilization. The keys elements from the definitions are an equilibrium between an imports of a long-range orientation from companies, together with equal importance long-range financial stability. It's important to recognize the context the strategy leadership is the organizational status, style that upper management may employees (Rowe, W. G., 2001).

\section{Strategic Leaders}

Strategic Leaders is comparatively rare. Those are the synergistic collection of what is best on both the Leaders and the administrative. This can equilibrium a more longrange financial, and operation need for companies together with a long-range strategy opportunity the may be inventory. Those merged a vision, innovative and indispensable for long-range successful with an operation concentrate, and understand retain organizational stability. Strategy Leaders is capable of link with the people around him and have powerful performance expectation.

As an outcome the capability into equilibrium shorts and long terms strategy requisites from companies. Therefore, Strategy Leaders make them fortune in companies. Noted previous would be a much-cited example of a Strategy Leaders, Both of those managers using the vision, creativity and power to inventions them respective the companies and made their leaders in the private sector. Was balancing while for the strong administrative and the operation understood from the businesses.

The doesn't mean an imaginative or administrative style of leaders is no longer wanted. Together of that style contributing to companies and into large administration the performance, but those must be equiponderant into earning a benefit together bring into companies. A predominant a visionary might lead to overly the risky strategy resolutionmake, timely the reservation administration styles will probably outcome on the advised resolution the leads into organizational concurrence decline over-time.

\section{METHODOLOGY OF RESEARCH}

This study will be carried out into achieve the above objectives, including exploration and morphology by nature and conducting interviews based on the form of the questionnaire. The research methodology defines the purpose of the research, how it works, how to measure progress, and what constitutes success with regard to the specific objectives of the research study. Research design is to identify methods and procedures for obtaining the information needed to structure or solve the problem. It is the overall operational pattern or framework for a project that stimulates information to be collected from any source and action. Based on the main purpose of our investigation, exploratory research was found to be the most appropriate. This type of research has the primary purpose of developing insights on the problem. Examines the main area where the problem lies and also tries to evaluate some appropriate courses of action. The tool used to collect data was in the form of a questionnaire. The questionnaire was used because it facilitates the scheduling and analys is of the data to be collected. The collected data were subjected to simple frequency distribution and percentage analys is.

\section{Data analysis and interpretation}

A factor analysis using to evaluate the validity (Cronbach's alpha) to assess the reliability of questionnaires.

Table 1 Reliability Statistics

\begin{tabular}{|c|c|c|c|c|}
\hline Section & $\begin{array}{c}\text { Scale Mean if } \\
\text { Item Deleted }\end{array}$ & $\begin{array}{c}\text { Scale Variance if } \\
\text { Item Deleted }\end{array}$ & $\begin{array}{c}\text { Corrected Item- } \\
\text { Total Correlation }\end{array}$ & $\begin{array}{c}\text { Cronbach's Alpha } \\
\text { if Item Deleted }\end{array}$ \\
\hline x9 & 9.37 & 3.682 & .596 & .628 \\
x10 & 9.52 & 3.599 & .459 & .708 \\
x11 & 9.44 & 3.907 & .488 & .686 \\
x12 & 9.51 & 3.457 & .549 & .650 \\
\hline
\end{tabular}


Table 1 shows, the Cronbach's Alpha, a measure of samples efficiency was conduct to identify if enough related subsistence between the features of the individual components in all a section from questionnaires. Cronbach's Alpha statistic, the Correlation statistic is specific when using this experience. (Cronbach's Alpha) statistic of larger from 0.708 , the associated of fewer from or egalitarian into 0.650 , and the anti-image interrelationship statistic of large from 0.628 suggest enough interrelationship available to the factors analysis.
Once an appropriate correlation from finding between component evaluations within a specific dimension, a factors analysis for a distance should be performed. Principal, the factor analysis (true-employees analysis) was used together with the perverse turning (Cronbach's Alpha). A factor load of the large in or equal into 0.686 this is the designer of the relationship between components. A restructuring competencies' outcome to all of a dimension.

Table 2 shows, Cronbach's alpha was used to identifying a reliably from questionnaires used on the studying.

\begin{tabular}{|c|c|c|c|c|}
\hline Section & $\begin{array}{c}\text { Scale Mean if } \\
\text { Item Deleted }\end{array}$ & $\begin{array}{c}\text { Scale Variance if } \\
\text { Item Deleted }\end{array}$ & $\begin{array}{c}\text { Corrected Item- } \\
\text { Total Correlation }\end{array}$ & $\begin{array}{c}\text { Cronbach's Alpha } \\
\text { if Item Deleted }\end{array}$ \\
\hline x13 & 9.06 & 3.302 & .528 & .624 \\
x14 & 8.85 & 3.900 & .524 & .629 \\
x15 & 9.01 & 3.815 & .512 & .633 \\
x16 & 8.97 & 3.957 & .421 & .686 \\
\hline
\end{tabular}

Values range between .624 and .686; while 3.957 indicates exemplary reliability, the values .421 is considered to be an abatement level of acceptability. A reliable statistic for all of a specific factor is presented. Therefore, it's clear for Table 2, the Cronbach's alpha to all of a specified factor is well over abatement frontier of acceptable from 3.957. The outcome indicates questionnaires used in studying has the height level of reliable. Table with an item-total value for an individual component of all of a specified factor has been comprised in this study, this table indicates that all of the components relate to the specified factors and a coefficient (Cronbach's alpha) values of specified factors will not be increased if some from the components left out.

Table 3 Perceived effectively of the strategic leadership implementation

\begin{tabular}{|l|c|c|c|c|c|c|}
\hline \multicolumn{1}{|c|}{ statements } & $\begin{array}{c}\text { No } \\
\text { range } \\
(\%)\end{array}$ & $\begin{array}{c}\text { Small } \\
\text { range } \\
(\%)\end{array}$ & $\begin{array}{c}\text { Moderate } \\
\text { range } \\
(\%)\end{array}$ & $\begin{array}{c}\text { Large } \\
\text { range } \\
(\%)\end{array}$ & $\begin{array}{c}\text { Very } \\
\text { largerange } \\
(\%)\end{array}$ & $\begin{array}{c}\text { criterion } \\
\text { deviation }\end{array}$ \\
\hline $\begin{array}{l}\text { Has your company get a } \\
\text { strategical and a clear vision in } \\
\text { the future }\end{array}$ & 5.80 & 2.826 & .512 & .739 & .751 & .499 \\
\hline $\begin{array}{l}\text { Does the message of your } \\
\text { company give a real sense to } \\
\text { associate all contents of the } \\
\text { strategical trend }\end{array}$ & 5.792 & 2.324 & .686 & .540 & .839 & .369 \\
\hline $\begin{array}{l}\text { Does your company explain the } \\
\text { dangers and the obstructions } \\
\text { which they have to be avoided }\end{array}$ & 5.89 & 2.421 & .350 & .663 & & .568 \\
\hline
\end{tabular}

The response indicates that though a supermajority's of respondents are of concepts the companies are effective at implementation strategic leadership, this still perceives the gaps between an effectual formulation and execution of strategic leadership on the oil companies. Recalling the levels of relation into the efficiency of strategic leadership achievable and whether established strategies is implementing to the full potential. 


\section{CONCLUSION}

Strategic leadership is reintegration to an administration and into the success of all companies. Those are explicit relations between the ability, and performance of a president and senior administration teams of the companies and the success of the companies. Senior administration teams impact each stage on a strategic leadership process. A resolution and action from a President and the senior administration, whether it is adjusting a strategic leadership of orientation of companies, or use the company's core competencies for competitors advantage, the effect on the developing and achievable of a strategy of companies.

Parallel, those number from the related style of strategic leaders the senior administration may publication, was depended on those individual distinctive and experiment. Companies and senior administration need to use the appropriate equilibrium of strategic leaders' style to improve the potential of the long-range strategy effectiveness. should contend this ideally the President and maybe others senior administration must using the "strategy leadership style", however at the ridiculously least conclude the senior administration teams must seek an equilibrium between over visionary strategy leadership styles and more strategic leadership styles. Finally, appropriate senior administration leadership actions and leadership style is integration to companies the strategic efficiency and long-term success.

\section{REFERENCES}

[1] Boal, K. B., and Hooijberg, R. (2001). Strategic leadership research: Moving on. The Leadership Quarterly, 11(4), 515-549.

[2] Boal,K. B. (2004, August 17-20). Strategic leadership, organizational learning and network ties (Keynote Paper and address). Strategic leadership on both sides of the Atlantic Symposium on Strategic Leadership. Switzerland: The International Institute for Management Development.

[3] Crossan, M., Vera, D., and Nanjad, L. (2008). Transcendent leadership: Strategic leadership in dynamic environments. The Leadership Quarterly, 19(5), 569-581.

[4] Felin, T., and Foss, N . (2005). Strategic organization: A field in search of micro-foundations. Strategic Organization, 441-455.

[5] Finkelstein, S., Hambrick, D. C., and Cannella, A. A . (2009). Strategic Leadership: Theory and Research on Executives. Top Management Teams, and Boards. New York: Oxford University Press.
[6] Hambrick. D. C., and Mason, P. A. (1984). Upper echelons: The organization as a reflection of its top managers. Academy of Management Review, 9(2), 193-206.

[7] Hitt, I., Ireland, R., and Hoskisson, R. E. (1995). Strategic management-competitiveness and globalization-concepts. THOMSON ( ( 1 st ed.). West Publishing Company.

[8] Hitt, M.A., Ireland, R.D. and Hoskisson, R.E . (2007). Strategic Management: Competitiveness and Globalization. 7th edition. Ohio: Thomson/South Western.

[9] Ireland, R. D., and Hitt, M. A. (2005). Achieving and maintaining strategic competitiveness in the $21 \mathrm{st}$ century : The role of strategic leadership. Management, 19(4), 63-77.

[10] Rowe, W. G. (2001). Creating Wealth in Organisations: The Role of Strategic Leadership. Academy of Management Review, 15(1).

[11] Rumsey, M. G. (2013). The Oxford Handbook of Leadership .( 1 st ed.). New Yorke: OUP USA.

[12] Sirmon, D., Hitt, M., and Ireland, R. D. (2007). Managing firm resources in dynamic environments to create value: Looking inside the black box. The Academy, 32(1), 273-292.

[13] Thomas W. (2010). Iraq's Petroleum Industry:Unsettled Issues. Middle East Institute Viewpoints: Iraq's Petroleum Industry: Unsettled Issues $\bullet$ www.mei.edu.

[14] Thompson, A.A. and Strickland, A.J. ( 2003). Strategic Management: Concepts and Cases 13th. edition. New York: McGraw-Hill. 